\title{
Anticholinesterase Effect of Eserine (Physostigmine) in Fish and Crustacean Species
}

\author{
José M. Monserrat and Adalto Bianchini \\ Laboratório de Zoofisiologia, Departamento de Ciências Fisiológicas, Fundação Universidade do Rio Grande, \\ Caixa Postal 474, 96201-900, Rio Grande-RS, Brazil.
}

\begin{abstract}
The kinetic characteristic $\left(K_{m}\right)$ of cholinesterase from the crab Chasmagnathus granulata, the shrimp Farfantepenaeus paulensis and the fish Odontesthes bonaeriensis were compared and correlated with the anticholinesterasic effect of eserine (physostigmine). For the crustaceans, the estimated $K_{m}$ values were about 5-8 times higher than that estimated for the fish $(0.04 \mathrm{mM})$. In the crab and the shrimp, the concentration of eserine which inhibited $50 \%$ of cholinesterase activity $\left(I C_{50}\right)$ was estimated as $5.33 \times 10^{-4}$ and $4.33 \times 10^{-4} \mathrm{mM}$, respectively. In both cases, it was significantly higher $(P<0.05)$ than that estimated for the fish larvae $\left(7.43 \times 10^{-5} \mathrm{mM}\right) . A$ high $\mathrm{K}_{\mathrm{m}}$ could reflect a lower affinity of the cholinesterase for its natural substrate, acetylcholine, or for substrate analogues such as carbamates and organophosphorous pesticides. If we consider the $I_{50}$ for eserine as an index of enzyme susceptibility to pesticide inhibition, the cholinesterase from the fish larvae may be a better useful tool in assays for pesticide biomonitoring than that from crustacean species.
\end{abstract}

Key words: Eserine; physostigmine; acetylcholinesterase; fish; silverside fish; crustacean

\section{INTRODUCTION}

Several pesticides, such as carbamates and organophosphorous, are known to be cholinesterase inhibitors. Some experimental work has shown a persistent cholinesterase inhibition after exposure to these agents (Da Silva et al., 1993). Further, relationships between physicochemical properties of organophosphorous compounds and their acute toxicity to guppies has been established (de Bruijn \& Hermens, 1993). However, little is known about the relationship between the kinetic properties of cholinesterase from aquatic organisms and the inhibitory effects of anticholinesterase pollutants. This kind of information may be useful, since it seems a rational criteria to select aquatic organisms to be used as bioindicators. This is an important point to be considered, since some toxicants can differently affect distinct species due to their physiological and/or biochemical differences.

In quantitative structural analysis relationship (QSAR) studies, biological variability is fixed, i.e. an unique species is employed. In this case, the toxicity of several pesticides is correlated with their physico-chemical properties like $\mathrm{K}_{\mathrm{ow}}$ (de Bruijn \& Hermens, 1993). In the present study, we selected a known anticholinesterase agent (eserine) and then correlated its inhibitory effect with a kinetic parameter $\left(\mathrm{K}_{\mathrm{m}}\right)$ of the cholinesterase from the crustaceans Chasmagnathus granulata (Decapoda: Grapsidae) and Farfantepenaeus paulensis (Decapoda: Penaeidae) and the fish Odontesthes bonaeriensis (Teleostei: Atherinidae). The crab $C$. granulata, a typical salt marsh species from Southern Brazil, has been used in toxicological studies (Rodríguez \& Lombardo, 1991). The shrimp F. paulensis, and the fishes of 
the genus Odontesthes, are important fishing resources. They have also been used in bioassays (Wasielesky et al., 1994).

\section{MATERIALS AND METHODS}

Adult male crabs Chasmagnathus granulata $(9.72$ $\pm 0.15 \mathrm{~g} ; \quad \mathrm{N}=22)$ and juvenile shrimps Farfantepenaeus paulensis $(2.65 \pm 0.13 \mathrm{~g} ; \mathrm{N}=19)$ were collected in salt marshes near the city of Rio Grande (Southern Brazil). In the laboratory, they were maintained at $20^{\circ} \mathrm{C}$ and $20 \%$ salinity. Three months aged larvae of Odontesthes bonaeriensis $(0.15 \pm 0.02 \mathrm{~g} ; \mathrm{N}=20)$ were obtained as previously described (Bianchini et al., 1997) and maintained at $20^{\circ} \mathrm{C}$ and $10 \%$ salinity. The area where all animals were collected is considered to be free of anticholinesterase pollutants (Almeida et al., 1993).

The thoracic and the sub-esophageal ganglia from the crab and shrimp respectively, were isolated and used as enzyme source. The fish was frozen and then decapitated, the head being employed as enzyme source. Tissues were kept frozen $\left(-20^{\circ} \mathrm{C}\right)$ not longer than one week. All samples were weighed and homogenized (crustaceans: $2 \% \mathrm{w} / \mathrm{v}$; fish: $5 \% \mathrm{w} / \mathrm{v}$ ) employing cold phosphate buffer (crustaceans: $0.25 \mathrm{M}, \mathrm{pH} 7.40$; fish: $0.05 \mathrm{M}, \mathrm{pH}$ 7.40) (Habig et al., 1988). Homogenates were then centrifuged at $8,100 \mathrm{~g}$ for $20 \mathrm{~min}$ at $4^{\circ} \mathrm{C}$. The supernatant was used as cholinesterase source. Cholinesterase activity was determined using a colorimetric method (Ellman et al., 1961). Acetylthiocholine iodide (AcSCh, Fluka) was used as substrate. Rates of AcSCh hydrolysis $\left(25^{\circ} \mathrm{C}, \mathrm{pH}\right.$ 7.40) were determined in duplicate, using substrate concentrations ranging from 0.24 to $9.24 \mathrm{mM}$ (crab), 0.20 to $7.84 \mathrm{mM}$ (shrimp), and 0.08 to 3.63 $\mathrm{mM}$ (fish). $\mathrm{K}_{\mathrm{m}}$ and $\mathrm{V}_{\max }$ values were estimated after Eadie-Hofstee transformation. Homogenate protein content was determined using a commercial kit (Microprote ${ }^{\circledR}$, Doles Ltda, Brazil), which is based on the method described by Bradford (1976).

The concentrations used for in vitro estimation of the eserine (Sigma) concentration that inhibited $50 \%$ of cholinesterase activity $\left(\mathrm{IC}_{50}\right)$ ranged from $2 \times 10^{-5}$ to $7 \times 10^{-3} \mathrm{mM}$ for the crustacean species (in triplicate) and from $10^{-6}$ to $1.12 \times 10^{-2} \mathrm{mM}$ for the fish species (in duplicate). The enzyme was exposed to the inhibitor during $5 \mathrm{~min}\left(25^{\circ} \mathrm{C}, \mathrm{pH}\right.$ 7.40) before measurements of cholinesterase activity.

The $\mathrm{IC}_{50}$ for the three species were estimated using probit analysis (Finney, 1971) and then compared, considering the higher $\mathrm{IC}_{50} /$ lower $\mathrm{IC}_{50}$ ratio $(\alpha=$ 0.05 ) as previously described (Rodríguez \& Lombardo, 1991). The $\mathrm{IC}_{50}$ values obtained in this experiment and other data from literature were correlated with their respective $\mathrm{K}_{\mathrm{n}}$ values, using regression analysis after logarithmic transformation of both variables.

\section{RESULTS AND DISCUSSION}

In the crustacean species, the $\mathrm{K}_{\mathrm{m}}$ values estimated for cholinesterase were about 5-8 times higher than that estimated for the fish species. The $\mathrm{IC}_{50}$ for eserine in $C$. granulata and $F$. paulensis cholinesterases were estimated as $5.33 \times 10^{-4}$ and $4.33 \times 10^{-4} \mathrm{mM}$, respectively. These values were significantly higher than that estimated in $O$. bonaeriensis $\left(7.43 \times 10^{-5} \mathrm{mM}\right)$ (Table 1$)$.

For the three species tested, high concentrations of the substrate (AcSCh) induced an inhibition of the cholinesterase activity. Considering $\mathrm{V}_{\max }$ as $100 \%$, inhibition was of 14.1 and $24.5 \%$ when 4.62 and $9.24 \mathrm{mM}$ ATCh, respectively, were employed in $C$. granulata. In $F$. paulensis and $O$. bonaeriensis, the inhibition was of 13.0 and $47.8 \%$, employing 7.63 and $3.63 \mathrm{mM} \mathrm{AcSCh}$, respectively (Fig. 1).

The specific cholinesterase activity was higher for the crustacean species than for $O$. bonaeriensis. However, slight differences were observed when $\mathrm{V}_{\max }$ of each species was related to their respective $\mathrm{K}_{\mathrm{m}}$ value. It must be noted that the enzyme source for $O$. bonaeriensis was the whole head, while for $C$. granulata and $F$. paulensis were the thoracic and subesophageal ganglia, respectively. Probably, proteins other than cholinesterase were more abundant in $O$. bonaeriensis than in crustaceans homogenates, resulting in a lower specific enzyme activity for the fish species. On the other hand, the inhibition registered at high substrate concentration suggest the possibility that the cholinesterases of the three species were acetylcholinesterases (Habig et al., 1988). 
Using the $\mathrm{K}_{\mathrm{m}}$ and $\mathrm{IC}_{50}$ values estimated in the present study, and those estimated by other authors for different species, a positive and significant relationship between the logarithmic values of $\mathrm{K}_{\mathrm{m}}$ and $\mathrm{IC}_{50}$ was observed $(\mathrm{r}=0.96 ; \mathrm{N}=10 ; \mathrm{P}<0.05$; Fig. 2).

Despite of the fact that the literature not always mentions the inhibition time used, a positive and significant relationship between the logarithmic values of $\mathrm{K}_{\mathrm{m}}$ and $\mathrm{IC}_{50}$ was observed. When estimating this relationship, we assumed that the threshold inhibition level was reached in all cases. Although this assumption could not be checked, a very good correlation between the two variables was observed $(\mathrm{r}=0.96)$.

Table 1 - Cholinesterase kinetic parameters $\left(\mathrm{K}_{\mathrm{m}}\right.$ and $\mathrm{V}_{\max }$ ) and concentrations of eserine which inhibit $50 \%$ of enzyme activity $\left(\mathrm{IC}_{50}\right)$ in Chasmagnathus granulata, Farfantepenaeus paulensis, and Odontesthes bonaeriensis. Equal letters represent means not significantly different $(\mathrm{P}>0.05)$ for each parameter analyzed. $\mathrm{K}_{\mathrm{m}}$ and $\mathrm{IC}_{50}$ were expressed in $\mathrm{mM}$. $\mathrm{V}_{\max }$ was expressed in $\mu$ moles. $\mathrm{mg}$ protein ${ }^{-1} \cdot \mathrm{min}^{-1}$.

\begin{tabular}{|c|c|c|c|}
\hline Species & $\begin{array}{c}\mathrm{K}_{\mathrm{m}} \\
( \pm 1 \mathrm{SE})\end{array}$ & $\begin{array}{c}\mathrm{V}_{\max } \\
( \pm 1 \mathrm{SE})\end{array}$ & $\mathrm{IC}_{50}$ \\
\hline C. granulata & $\begin{array}{c}0.28 \pm 0.03 \\
\text { (A) }\end{array}$ & $\begin{array}{c}1.76 \pm 0.05 \\
\text { (A) }\end{array}$ & $\begin{array}{c}5.33 .10^{-4} \\
\text { (A) }\end{array}$ \\
\hline F. paulensis & $\begin{array}{l}0.19 \pm 0.02 \\
\quad(\mathbf{B})\end{array}$ & $\begin{array}{c}1.41 \pm 0.04 \\
\text { (B) }\end{array}$ & $\begin{array}{c}4.33 .10^{-4} \\
\text { (A) }\end{array}$ \\
\hline O. bonaeriensis & $\begin{array}{c}0.04 \pm 0.01 \\
\quad(\mathbf{C})\end{array}$ & $\begin{array}{c}0.26 \pm 0.01 \\
(\mathbf{C})\end{array}$ & $\begin{array}{c}7.43 .10^{-5} \\
\text { (B) }\end{array}$ \\
\hline
\end{tabular}

Some authors have reported that insect resistance to carbamate or organophosphorous pesticides could be related to high $\mathrm{K}_{\mathrm{m}}$ values (Fournier \& Muero, 1994). A high $K_{m}$ could reflect a lower affinity of the cholinesterase protein for its natural substrate, acetylcholine, or for substrate analogues such as carbamate and organophosphorus pesticides. Considering $\mathrm{IC}_{50}$ for eserine as an index of enzyme sensitivity to pesticide inhibition, a positive relationship with $\mathrm{K}_{\mathrm{m}}$ values was expected, as indeed observed. According to our data, $O$. bonaeriensis could be a better in vitro bioindicator, since its acetylcholinesterase presents a lower $\mathrm{K}_{\mathrm{m}}$ and a correspondingly lower $\mathrm{IC}_{50}$ than C. granulata and $F$. paulensis acetylcholinesterases.
When considering the advantages of in vitro assays, fastness and simplicity are obvious. However, one should consider if the in vitro results reflect or not the in vivo processes. It

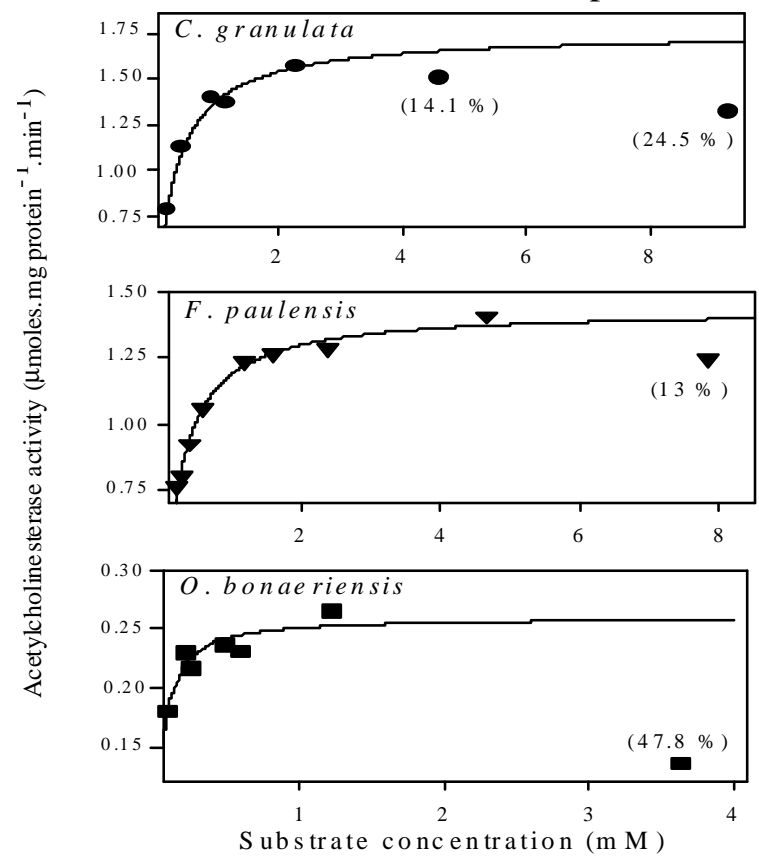

Figure 1 - Substrate concentration and acetylcholinesterase activity relationship for Chasmagnathus granulata, Farfantepenaeus paulensis and Odontesthes bonaeriensis. Values into brackets represent enzyme inhibition registered at high substrate concentration.

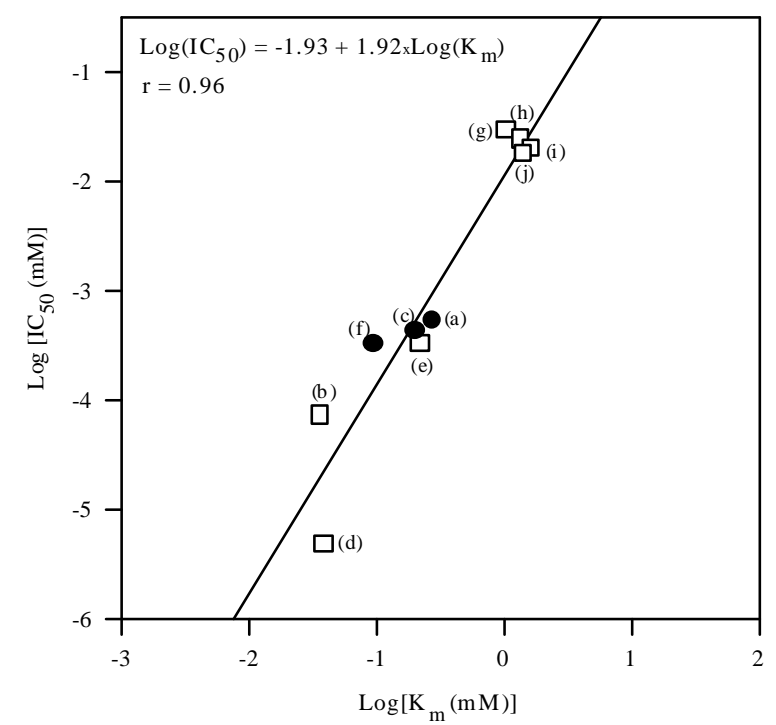

Figure 2 - Relationship between $\mathrm{IC}_{50}$ for eserine and cholinesterase $K_{\mathrm{m}}$ values for different species of $(\bullet)$ crustacean and ( ) fish species. (a), (b) and (c) are data from the present study; (d) is from Magnotti et al. (1994); (e) and (f) are from Habig et al. (1988); (g), (h), (i) and (j) are from Kabeer Ahmmad Sahib \& Ramana Rao (1980). 
must be noted that animal sensitivity to organophosphorous compounds is related to the dynamics of activation and deactivation of these compounds. Differences in the rates of these processes, for example, can explain the differences in toxicity of these compounds to rats of different sex and age (Murphy et al., 1968). More recent work (Thompson et al., 1995) showed that the $\mathrm{LD}_{50}$ of different organophosphorous compounds for avian species were well correlated with in vitro $\mathrm{IC}_{50}$ for brain cholinesterase ( $\left.\mathrm{r}=0.88\right)$, suggesting that a variable which integrated in vivo toxicological processes could be predicted by an in vitro measure of toxicity. Thus, it could be reasonable to consider in vitro enzyme sensitivity as a good criterion for selection of species to be employed as monitors of anticholinesterase compounds.

Another aspect to be considered is if the sensitivity to one compound, such as eserine, implies in general sensitivity. We re-analyzed some previous results (Wang \& Murphy, 1982) in order to correlate in vitro $\mathrm{IC}_{50}$ for different species and distinct anticholinesterase compounds. There was a strong relationship between pairs of $\mathrm{IC}_{50}$ of different organophosphrous compounds (Table 2), suggesting that sensitivity to one specific compound could indicate a general sensitivity. Also, $\mathrm{IC}_{50}$ values present a high and significant $(\mathrm{P}$ $<0.05)$ correlation with a more specific inhibitor measure, such as the bimolecular inhibition constant $\left(\mathrm{K}_{\mathrm{i}}\right)$, which quantifies the proportion between inhibited enzyme and the complex inhibitor-enzyme (Fig. 3). At this point, it can be hypothesized that general sensitivity of cholinesterase to organophosphorous and carbamates compounds can be estimated using kinetic parameters, like $\mathrm{K}_{\mathrm{m}}$.

There are several theories to explain differences in enzyme sensitivity to anticholinesterasic compounds. Some authors determined the cholinesterase activity of resistant and nonresistant arthropods strains to organophosphorous (Zahavi et al., 1971). The non-resistant strains showed a greater enzyme activity than the resistant strain, when butirylthiocholine iodide (BuSCh) was employed as substrate, and lower when acetylthiocholine iodide (AcSCh) was used.
Table 2 - Correlation between $\mathrm{IC}_{50}$ (expressed in $\mathrm{M}$ ) of several organophosphorous pesticides for cholinesterases of different animal species (Rana sp., Gallus domesticus, Cavia porcellus, Macaca fascicularis, Rattus rattus and Ictalurus sp.). Values into brackets represents the p-value for the correlation test. The analysis was made using data reported by Wang \& Murphy (1982).

\begin{tabular}{cccccc}
\hline & DFP & MP & P & G & EG \\
\hline DFP & - & 0.98 & 0.96 & 0.96 & 0.99 \\
& & $(0.001)$ & $(0.002)$ & $(0.003)$ & $(0.000)$ \\
\hline Methyl & 0.98 & - & 0.98 & 0.90 & 0.95 \\
paraoxon & $(0.001)$ & & $(0.001)$ & $(0.013)$ & $(0.003)$ \\
(MP) & & & & & \\
\hline Paraoxon & 0.96 & 0.98 & - & 0.91 & 0.95 \\
$(\mathrm{P})$ & $(0.002)$ & $(0.001)$ & & $(0.013)$ & $(0.003)$ \\
\hline Gutoxon & 0.96 & 0.90 & 0.91 & - & 0.99 \\
$(G)$ & $(0.003)$ & $(0.013)$ & $(0.013)$ & & $(0.000)$ \\
\hline $\begin{array}{c}\text { Ethyl gutoxon } \\
\text { (EG) }\end{array}$ & 0.99 & 0.95 & 0.95 & 0.99 & - \\
\hline
\end{tabular}

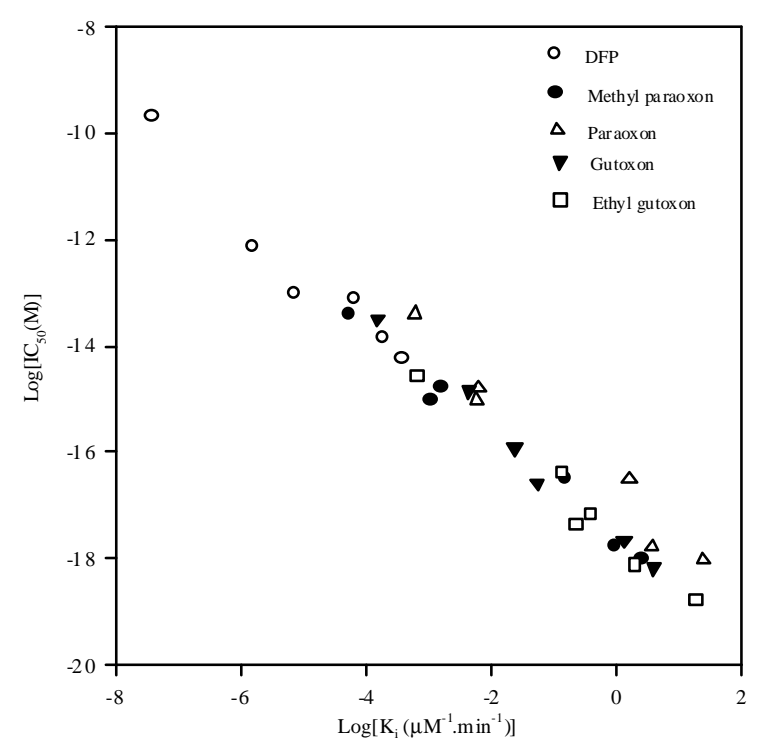

Figure 3 - Correlation between in vitro $\mathrm{IC}_{50}$ of different organophosphorous and bimolecular inhibition constant $\left(\mathrm{K}_{\mathrm{i}}\right)$ for cholinesterases of different animal species (Rana sp., Gallus domesticus, Cavia porcellus, Macaca fascicularis, Rattus rattus e Ictalurus sp.). The analysis was made using data reported by Wang \& Murphy (1982).

The activity quotient $\mathrm{BuSCh} / \mathrm{AcSCh}$ was estimated as 0.16 and 0.05 for non-resistant and resistant strains, respectively. This data suggested that the esteratic site of the cholinesterase of nonresistant species was greater than that of resistant ones. This in turn could lead to higher probability of inhibitor-enzime complex formation in nonresistant species. 
For C. granulata cholinesterase, we registered an activity quotient higher than that reported for the sensitive cholinesterases from the arthropod Tetranychus cinnabarinus (Zahavi et al., 1971). It was estimated as 0.25 , since the activity registered was 0.34 and $1.37 \mu$ moles.mg protein ${ }^{-1} \cdot \mathrm{min}^{-1}$ when $1.2 \mathrm{mM}$ of AcSCh and $1.11 \mathrm{mM}$ of BuSCh was employed, respectively. It remains to be determined the $\mathrm{BuSCh} / \mathrm{AcSCh}$ quotient for a more sensitive species to eserine, such as $O$. bonaeriensis. Finally, it must be noted that in the available literature only one work has reported in vitro sensitivity of acetylcholinesterases to organophosphorous compounds to be lower for marine invertebrates (Palaemon serratus and Mytilus edulis) than for fishes (Galgani \& Bocquéné, 1990).

\section{ACKNOWLEDGEMENTS}

We thank M. L. Bolkovic and E.A. Santos for careful reading of the manuscript, R. Robaldo for technical assistance, and Doles Reagentes Ltda. for material support. J. M. Monserrat was recipient of a CAPES fellowship. A. Bianchini is a research fellow from Brazilian CNPq (Proc. 300536/90-9).

\section{RESUMO}

As caraterísticas cinéticas $\left(\mathrm{K}_{\mathrm{m}}\right)$ de colinesterases do caranguejo Chasmagnathus granulata, o camarão Farfantepenaeus paulensis e o peixe Odontesthes bonaeriensis foram comparadas e correlacionadas com os efeitos anticolinesterásicos da eserina (fisostigmina). Nos crustáceos, o valores estimados de $\mathrm{K}_{\mathrm{m}}$ foram aproximadamente 5-8 vezes maiores do que aquele estimado para a espécie de peixe $(0.04 \mathrm{mM})$. No caranguejo e camarão, a concentração de eserina que inibiu $50 \%$ da atividade colinesterásica $\left(\mathrm{CI}_{50}\right)$ foi estimada em $5.33 \times 10^{-4}$ e $4.33 \times 10^{-4} \mathrm{mM}$, respectivamente. Estes valores foram significativamente maiores $(\mathrm{P}<0.05)$ que aquele estimado para as larvas de peixes $\left(7.43 \times 10^{-5} \mathrm{mM}\right)$. Um valor de $\mathrm{K}_{\mathrm{m}}$ mais elevado poderia refletir uma menor afinidade da colinesterase pelo seu substrato natural, acetilcolina, ou análogos tais como inseticidas carbamatos e fosforados. Se a $\mathrm{CI}_{50}$ para eserina é considerada como um índice da susceptibilidade da enzima a inibição por inseticidas, logo a colinesterase de larvas de peixes poderiam ser uma ferramenta mais útil no monitoramento de inseticidas do que aquelas das espécies de crustáceos.

\section{REFERENCES}

Almeida, M. T.; Baumgarten, M. G.; Silva Rodrigues, R. M. (1993), Identificação de possíveis fontes de contaminação das águas que margeiam a cidade do Rio Grande. Documentos Técnicos - Oceanografia, Rio Grande .

Bianchini, A.; Monserrat, J. M.; Phonlor, G.; Oneto, M. L. (1997), Anticholinesterase effects of methyl parathion to juveniles of Odontesthes bonaeriensis (Teleostei: Atherinidae). Arq. Biol. Tecnol., 40, 225231.

Bradford, M. (1976), A rapid and sensitive method for quantitation of microgram quantities of protein utilizing the principle of protein-dye binding. Anal. Biochem., 72, 248-254.

Da Silva, H. C.; Guilherme Medina, H. S.; Fanta, E.; Bacila, M. (1993), Sub-lethal effects of the organophosphate FOLIDOL 600 (Methyl parathion) on Callichthys callichthys (Pisces: Teleostei). Comp. Biochem. Physiol., 105C, 197-201.

De Bruijin, J.; Hermens, J. (1993), Inhibition of acetylcholinesterase and acute toxicity of organophosphorus compounds to fish: a preliminary structure-activity analysis. Aquat. Toxicol., 24, 257274.

Ellman G. L.; Courtney D.; Andres Jr. V.; Featherstone, R. M. (1961), A new and rapid colorimetric determination of acetylcholinesterase activity. Biochem. Pharmacol., 7, 88-96.

Finney, D. J. (1971), Probit Analysis. Cambridge University Press, Cambridge.

Fournier, D.; Muero, A. (1994), Modification of acetylcholinesterase as a mechanism of resistance to insecticides. Comp. Biochem. Physiol., 108C, 19-31.

Galgani, F.; Bocquéné, G. (1990), In vitro inhibition of acetylcholinesterase from four marine species by organophosphates and carbamates. Bull. Environ. Contam. Toxicol., 45, 243-249.

Habig, C.; Di Giulio, R. T.; Abou-Donia, M. B. (1988), Comparative properties of channel catfish (Ictalurus punctatus) and blue crab (Callinectes sapidus) acetylcholinesterases. Comp. Biochem. Physiol., 91C, 293-300.

Kabeer Ahammad Sahib, I.; Ramana Rao, K. V. (1980), Correlation between subacute toxicity of malathion and acetylcholinesterase inhibition in the tissues of the teleost Tilapia mossambica. Bull. Environ. Contam. Toxicol., 24, 711-718. 
Magnotti Jr., R. A.; Zaino, J. P.; McConnell, R. S. (1994), Pesticide-sensitive fish muscle cholinesterases. Comp. Biochem. Physiol., 108C, 187-194.

Murphy, S. D.; Lauwerys, R. R.; Cheever, K. L. (1968), Comparative anticholinesterase action of organophosphorus insecticides in vertebrates. Toxicol. Appl. Pharmacol., 12, 22-35.

Rodríguez, E. M.; Lombardo, R. J. (1991), Acute toxicity of parathion and 2,4 D to estuarine adult crabs. Bull. Environ. Contam. Toxicol., 46, 576-582.

Thompson, H. M.; Langton, S. D.; Hart, A. D. M. (1995), Prediction of interespecific differences in the toxicity of organophosphorus pesticides to wildlife - a biochemical approach. Comp. Biochem. Physiol., 111C, 1-12.
Wang, C.; Murphy, S. D. (1982), Kinetic analysis of species difference in acetylcholinesterase sensitivity to organophosphate insecticides. Toxicol. Appl. Pharmacol., 66, 409-419.

Wasielesky, W. J.; Marchiori, M. A.; Santos, M. H. S. (1994), Efeito da amônia no crescimento de póslarvas do camarão rosa, Penaeus paulensis, PerezFarfante, 1967 (Decapoda: Penaeidae). Nauplius, 2, 99-105.

Zahavi, M.; Tahori, A. S.; Klimer, F. (1971), Insensitivity of acetylcholinesterase to organophosphorus compounds as related to size of esteratic site. Molec. Pharmacol., 7, 611-619.

Received: June 29, 1999; Revised: March 23, 2000; Accepted: July 18, 2000. 